\title{
Change of plasma lipoproteins by heparin-released lipoprotein lipase
}

\author{
Jeong-Yeh Yang ${ }^{1}$, Tae-Keun Kim ${ }^{1}$, Bon-Sun \\ Koo ${ }^{1}$, Byung-Hyun Park ${ }^{1}$ and Jin-Woo Park ${ }^{1,2}$ \\ 1 Department of Biochemistry, Chonbuk National University Medical School and \\ Institute for Medical Sciences, Chonju, Korea \\ 2 Corresponding author: Tel, 0652-270-3084; Fax, 0652-274-9833; E-mail, \\ jinwoo@moak.chonbuk.ac.kr
}

Accepted 17 March 1999

Abbreviations: LPL, lipoprotein lipase; VLDL, very low density lipoprotein; LDL, low density lipoprotein; HDL, high density lipoprotein

\section{Introduction}

Lipoprotein lipase (LPL) is an acylglycerol hydrolase (EC 3.1.1.34) which catalyzes the hydrolysis of triglyceride component in circulating chylomicron and very-low-densitylipoprotein (VLDL) into two fatty acids and monoacylglycerol (Bensadoun, 1991; Hide et al., 1992). The enzyme is found in extrahepatic tissues including adipose tissue, cardiac and skeletal muscles, lactating mammary gland, lung, spleen and brain (Braun and Severson, 1992), where it was suggested to function in the processes of lipid acquisition from circulating triglycerides.

LPL is produced by parenchymal cells in extrahepatic tissues and transferred to capillaries, where it acts (Olivecrona and Bengtsson-Olivecrona, 1987). LPL is attached to the luminal surface of vascular endothelial cells in a complex with membranebound heparan sulfate, and released into blood stream by heparin (Saxena et al., 1991).

The function of LPL is to direct the influx of plasma TG in forms of fatty acids into the peripheral tissues for storage or fuel. For this reason, the control of LPL activity is an important regulatory step for directing traffic of triglyceride-fatty acids to fulfill the energy requirements of peripheral tissues in a tissue-specific manner. The deficiency or dysfunction of LPL has been found in association with the pathogenesis of hypertriglyceridemia (Eckel, 1989)

Besides the lipolytic activity of LPL on chylomicron and VLDL, LPL is known to participate in an enhancement of cholesterol uptake by arterial endothelial cells (Rutledge and Goldberg, 1994; Beisiegel, 1996). But most of these studies were performed in vitro, and little is known about the LPLmediated cholesterol uptake in physiological state.

In this study, changes in blood lipid composition and level of lipoprotein were determined after the injection of heparin in human.

\section{Materials and Methods}

\section{Post-heparin plasma}

Plasma samples from normal healthy adults or patients with open heart surgery were obtained $15 \mathrm{~min}$ after the injection of $3 \mathrm{mg} / \mathrm{kg}$ body weight of heparin (Vilella et al., 1993). Blood was drawn into EDTA-containing tubes, and kept at $4^{\circ} \mathrm{C}$ until the separation of plasma.

\section{Assay of plasma lipolytic activity}


Lipolytic activity of plasma was measured as described by Park et al. (1995). A stock triacylglycerol emulsion containing $5 \mathrm{mCi}$ of tri $\left[9,10(\mathrm{n}){ }^{3} \mathrm{H}\right]$ oleoylglycerol (Amersham), 1.13 mmole of trioleoylglycerol, $60 \mathrm{mg}$ of 1- phosphatidylcholine (bovine liver) and $9 \mathrm{ml}$ of glycerol was prepared according to the method of Nilsson-Ehle and Schotz (1976). Before assay, 1 vol. of the stock emulsion, $19 \mathrm{vol}$. of $3 \% \mathrm{BSA}$ in $0.2 \mathrm{M}$ Tris $/ \mathrm{HCl}$ buffer $(\mathrm{pH} 8.1)$ and 5 vol. of heat-inactivated fasted rat serum (heated at $60^{\circ} \mathrm{C}$ for $30 \mathrm{~min}$ ) were mixed and incubated for $15-30 \mathrm{~min}$. $100 \mathrm{FI}$ of this activated substrate mixture was added to the same amount of enzyme solution, and incubated at $37^{\circ} \mathrm{C}$ for $60 \mathrm{~min}$. Released fatty acids were extracted and its radioactivity was measured. One $\mathrm{mU}$ of lipolytic activity represents the release of $1 \mathrm{nmole}$ of fatty $\mathrm{acid} / \mathrm{min}$.

\section{Immunoblotting of LPL}

LPL from an aliquot of plasma was concentrated using Heparin-Sepharose (Pharmacia LKB) (Park et al., 1996). After the addition of enough heparin-Sepharose equilibrated with $20 \mathrm{mM}$ Tris, $0.3 \mathrm{M} \mathrm{NaCl}$, and $1 \mathrm{M}$ glycerol $(\mathrm{pH}$ 7.4), mixture was kept on ice for 30 min with occasional mixing, washed 5 times with equilibration buffer, mixed with electrophoresis sample buffer $(62.5 \mathrm{mM}$ Tris, $2 \%$ SDS, 5\% 2-mercaptoethanol, 10\% glycerol, $0.001 \%$ bromophenol blue, $\mathrm{pH}$ 6.8), and boiled for $5 \mathrm{~min}$.

Proteins were separated by SDS-PAGE with $10 \%$ resolving and 3\% acrylamide stacking gel (Laemmli, 1970), and transferred to nitrocellulose membrane. The membranes were blocked with $2 \%$ BSA, and incubated overnight with anti-bovine LPL chicken IgG (kindly supplied by Dr. Thomas Olivecrona in Department of Physiological Chemistry, University of Umeä, Umeä, Sweden) and with alkaline phosphatase-conjugated anti-chicken IgG rabbit antiserum for $2 \mathrm{~h}$. Color was developed in BCIP/NBT solution.

\section{$\mathrm{NaBr}$ gradient ultracentrifugation of plasma lipoproteins}

Plasma lipoproteins were separated by $\mathrm{NaBr}$ density gradient ultracentrifugation in a swinging bucket rotor (Kelley \& Kruski, 1986). Inner surface of ultracentrifugation tube $(5 \mathrm{ml})$ was wetted with polyvinyl alcohol as described by Pitas and Mahley (1992). Plasma adjusted to the density of $1.31 \mathrm{~g} / \mathrm{ml}$ with $\mathrm{NaBr}$ $(0.5 \mathrm{ml})$ was placed at the bottom of tubes. Then the discontinuous gradient was formed above the plasma by layering the $\mathrm{NaBr}$ solutions with the density of 1.210 , $1.063,1.019$ and $1.006 \mathrm{~g} / \mathrm{ml}$ consecutively at the amount of $1.2,1.5,1.3$ and $0.5 \mathrm{ml}$ each. Each solution was pipetted down the inside of the tube (held at a 45 degree) with a slow continuous flow with great care to prevent the mixing. Centrifugation was performed at $34,000 \mathrm{rpm}$ for $16 \mathrm{~h}$ at $20^{\circ} \mathrm{C}$ in a Sorvall SW -650 swinging bucket rotor (DuPont-Sorvall, OTD-75B). The centrifuge tube was punctured from the bottom and a saturated $\mathrm{NaBr}$ solution was pumped into the bottom of the tube. About 25 fractions of $200 \mathrm{FI}$ were collected from the top.

\section{Triglyceride, cholesterol and protein determination}

Levels of total plasma triglyceride (Wahlfeld, 1974) and cholesterol (Siedel et al., 1983) were measured by enzymatic kit (Asan Co., Korea). Proteins were determined according to the method of Bradford (Bradford, 1976) using bovine serum albumin as reference standard.

\section{Results}

\section{Effect of Heparin administration on Plasma LPL concentration}

Changes in total lipolytic activity in the 13 plasma samples taken from human were measured after the injection of $3 \mathrm{mg} / \mathrm{kg}$ body weight heparin (Figure 1). The activity of lipoprotein lipase in plasma increased from 0 to $11.07+/$ $2.94 \mathrm{mU} / \mathrm{ml}$ within 30-40 min post-heparin administration and decreased to the basal level within $2 \mathrm{~h}$. Hepatic triglyceride lipase in addition to LPL is reported to be released into the plasma by heparin (Henderson et al.,

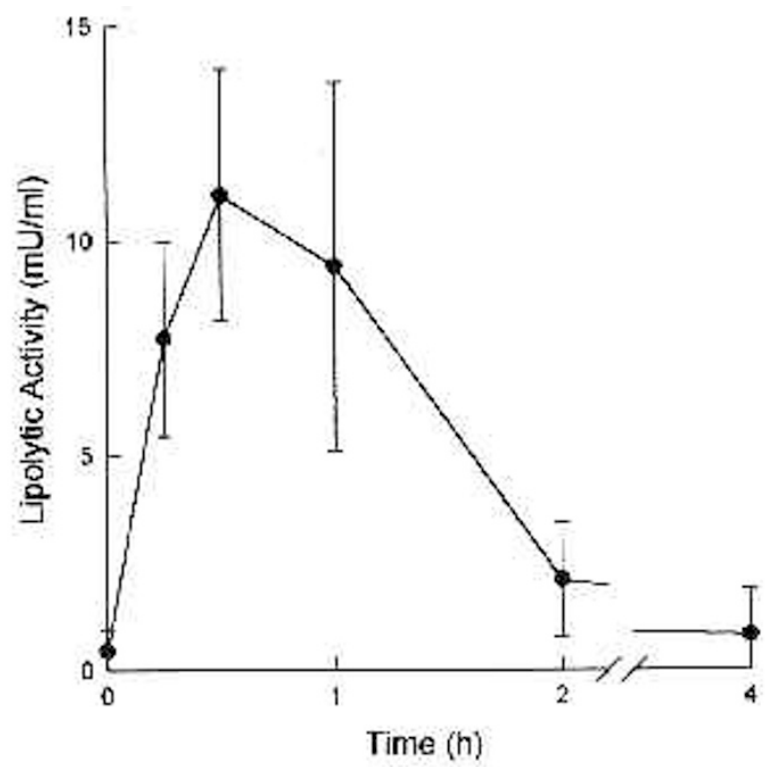

Figure 1. Changes in the total lipolytic activity of human plasma after heparin injection. Post-heparin plasma was obtained at various time intervals after the injection of $3 \mathrm{mg} / \mathrm{kg}$ body weight of heparin, and its lipolytic activity was determined as described under Materials and Methods. Data were expressed as mean \pm S.D. of three plasma samples except for 0 and 15 min data with 13 samples. 


\section{1) $\quad 15 \quad 30 \quad 80 \quad 120 \quad 240 \mathrm{~min}$ $-57 \mathrm{kCa}$}

Figure 2. Changes in the LPL protein in human plasma after heparin injection. Postheparin plasma was obtained as described in the legend of Figure 1, and LPL protein was immunoblotted.

1993). In order to determine a possible contribution of other tissue triglyceride lipase in the post-heparin plasma total lipolytic activity, Western blot analysis of the pooled plasma samples was immunoblotted with anti-bovine LPL. The immuno blot data in Figure 2 shows a single $57 \mathrm{kDa}$ band equivalent to a subunit molecular weight of LPL and also indicated that the change of LPL protein levels was similar to the change of total lipolytic activity reaching the maximum at $30 \mathrm{~min}$.

\section{Effects of heparin administration on total cholestrol and triglyceride concentration in plasma}

LPL is known to participate in an enhancement of lipoprotein uptake by arterial endothelial cells (Rutledge and Goldberg, 1994; Beisiegel, 1996). To determine the physiological significance of this LPL-mediated lipoprotein uptake, the changes of total cholesterol and triglyceride in plasma were studied after the injection of heparin to increase the free LPL in plasma (Figure 3). The concen-

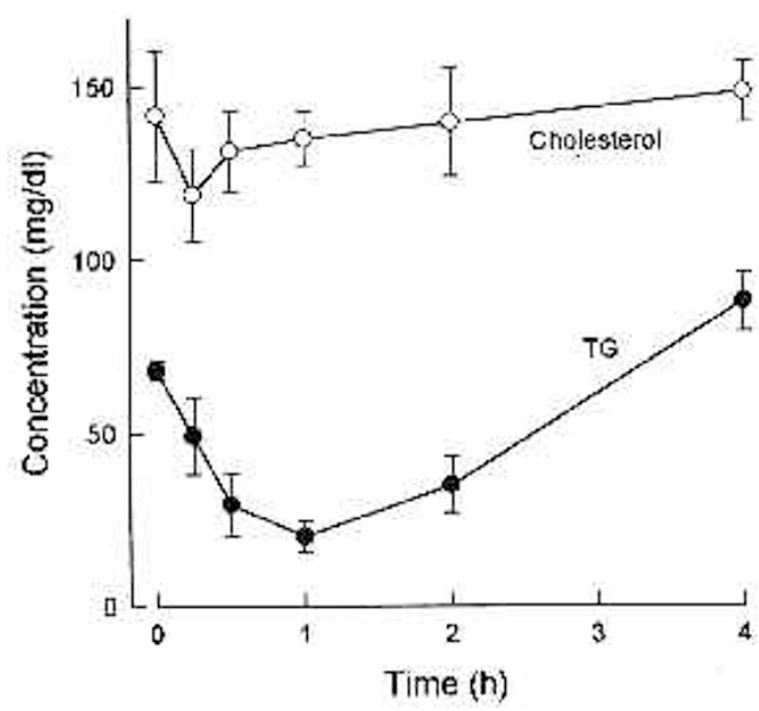

Figure 3. Changes in the total cholesterol and triglyceride concentration of human plasma after heparin injection. Post-heparin plasma was obtained as described in the legend of Figure 1, and triglyceride and cholesterol contents were determined as described under "Materials and Methods". Data were expressed as mean \pm S.D. of three plasma samples except for 0 and 15 min data with 13 samples. tration of plasma triglyceride was decreased from 68.12 \pm 2.70 to $20.16 \pm 4.60 \mathrm{mg} / \mathrm{dl}$ in $1 \mathrm{~h}$ after heparin injection and returned to normal level in $4 \mathrm{~h}$ without any significant change in total cholesterol level after heparin injection. This lowering and recovering of triglyceride concentrations showed a time-delayed results of LPL catalysis on triglyceride and coincide well with the elevation and fall of LPL levels in plasma post-heparin administration.

\section{Distribution of lipoproteins in plasma after heparin administration}

Plasma lipoproteins were separated by $\mathrm{NaBr}$ density gradient ultracentrifugation. As shown in Figure 4, VLDL, LDL and HDL were clearly separated as follow: VLDL at the top fraction, LDL around the 5th fraction, and HDL around the 16th fraction respectively. Plasma proteins

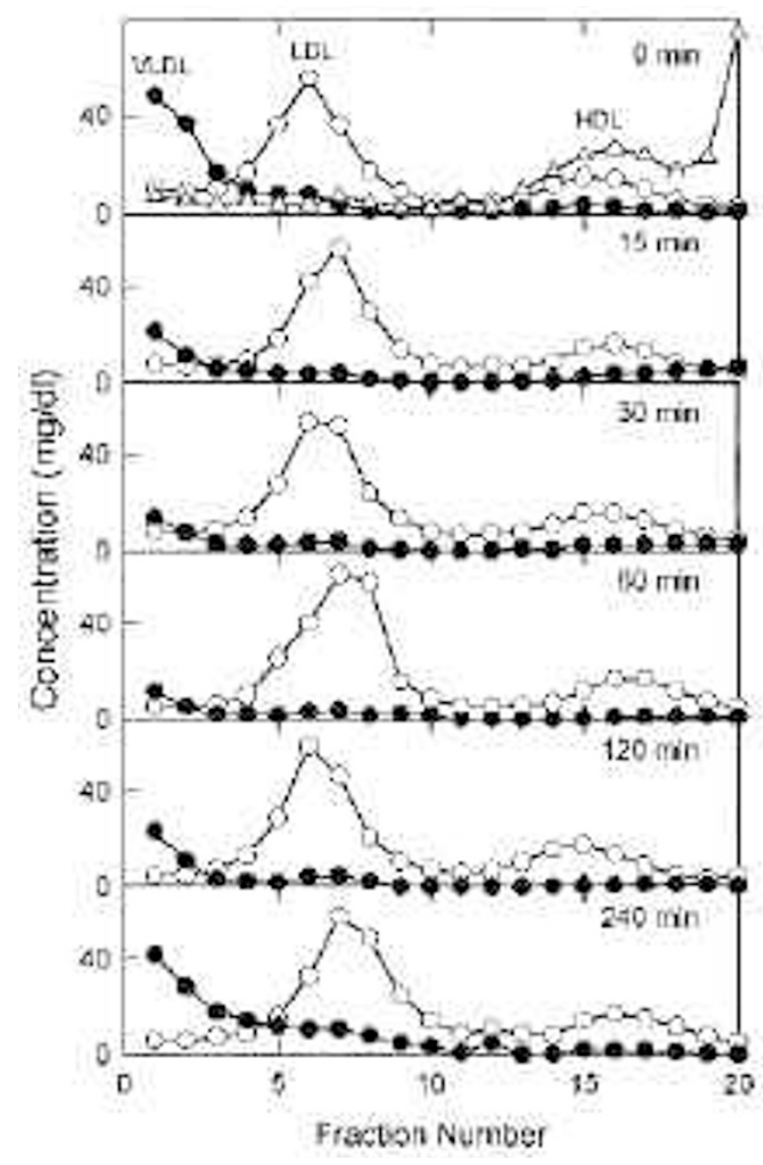

Figure 4. $\mathrm{NaBr}$ density gradient ultracentrifugation profile of normal human plasma lipoproteins after heparin injection. Post-heparin plasma was obtained as described in the legend of Figure 1. Lipoproteins were separated by $\mathrm{NaBr}$ density gradient ultracentrifugation as described under "Materials and Methods". Triglyceride (I), cholesterol ( $\mathrm{m}$ and protein ()) contents of each fraction were determined. Data represents the mean of three separate plasma samples. 
were found after the 20th fraction at the bottom. The lipoprotein profiles determined by the ultracentrifugation of plasma obtained at 15, 30, 60, 120 and 240 min after heparin injection showed that triglyceride content in VLDL decreased to the minimum value in $1 \mathrm{~h}$ and returned to normal level in $4 \mathrm{~h}$. But the level of cholesterol in LDL and HDL fractions was not changed with heparin injection.

\section{Discussion}

LPL is produced and secreted by parenchymal cells in extrahepatic tissues. Production of active LPL by cells involves synthesis and $\mathrm{N}$-linked glycosylation, dimerization of subunits, development of high affinity for heparin, and secretion (Braun and Severson, 1992; Masuno et al., 1992; Park et al., 1995). Secreted LPL is transferred to the capillary endothelium by mechanism unknown (Olivecrona and Bengtsson-Olivecrona, 1987). LPL is known to be attached to the luminal surface of vascular endothelial cells in a complex with membrane-bound heparan sulfate, and released into plasma by heparin (Saxena et al., 1991). Animal studies indicate that there is a continuous dissociation of enzyme from the endothelium to the blood (Bagby, 1983; Camps et al., 1990). LPL activity was not detectable in normal human plasma but trace amount of LPL protein present (Figure 2) may suggest that there may exist some basal level of LPL that are in an equilibrium state of dissociation with the endothelial cells.

The major classes of lipoproteins include triglyceriderich lipoproteins (chylomicrons and VLDL) and cholesterolrich lipoproteins (LDL and HDL). LDL receptor present ubiquitously in most cell types plays an important role for the cellular uptake of LDL (O'Brien and Chait, 1994). Brown and Goldstein (1983) reported that acetylated LDL was taken up by another cell surface receptor, namely 'scavenger receptor'. Oxidized LDL can be taken up by macrophage scavenger receptors leading to foam cell formation, stimulation of monocyte and inhibition of macrophage chemotaxis, and cytotoxicity (Steinberg et al., 1989; Witztum, 1993). Other potential mechanisms of cellular uptake of cholesterol include phagocytic uptake of aggregated LDL by macrophages (Hurt and Camejo, 1987; Salisbury et al., 1985; Vijayagopal et al., 1993), or immune complexes of lipoproteins via Fc receptor of macrophages (Bierman, 1992; Klimov et al., 1985; Witztum, 1993).

In 1975, Felts et al. (1975) proposed that LPL might be attached to the remnants and serves as a recognition signal for the liver, in addition to its lipolytic activity. Interest in this hypothesis was revived when Beisiegel et al. (1991) found that LPL was a ligand for the LDL receptor-related protein in hepatocytes and fibroblasts. Subsequently, it was shown in tissue culture that direct LPL-receptor interactions can enhance binding and cellular uptake of lipoproteins (Beisiegel, 1996).
There are reports that LPL may also enhance the cholesterol uptake by arterial wall cells in vitro (Rutledge and Goldberg, 1994; Beisiegel, 1996). Binding of LPLlipoprotein complexes to extracellular matrix or cell surface heparan sulfate proteoglycans causes them to be retained in the arterial wall (Saxena et al., 1992), or to bring them into a close approximation of LDL receptors (Mulder et al., 1993). All of these suggested pathways are based on in vitro observations using exogenously added LPL. Recently, Merkel et al. (1998) reported that LPL bridging of VLDL occurs in vivo using transgenic mice. However, little is known about LPL-mediated LDL uptake in human.

We tried a bolus injection of heparin to increase the free form of LPL in human plasma in vivo. After the injection of heparin, LPL activity and level of protein in plasma were rapidly increased, and reached the maximum in $30 \mathrm{~min}$. Plasma triglyceride was decreased and reached the minimum in 60 min after heparin injection, somewhat later than the peak of LPL, then it returned to normal level in $4 \mathrm{~h}$. In lipoprotein profiles obtained by $\mathrm{NaBr}$ gradient ultracentrifugation, VLDL decreased and returned to normal, however there were no significant changes in the level of LDL and HDL. These results suggest that, at least in normo-lipidemic subjects, increased free plasma LPL acts primarily on VLDL and failed to show any significant uptake of cholesterol-rich lipoproteins. Further studies are needed to evaluate the possibility that LPL-mediated LDL uptake might be important in hyperlipidemic or other pathologic conditions.

\section{Acknowledgement}

This work was supported by the grant provided from the Basic Medical Research Promotion Fund of the Ministry of Education, Republic of Korea (1996).

\section{References}

Bagby, G. J. (1983) Heparin-independent release of lipoprotein lipase activity from perfused rat hearts. Biochim. Biophys. Acta 753: 47-52

Beisiegel, U., Weber, W. and Bengtsson-Olivecrona, G. (1991) Lipoprotein lipase enhances the binding of chylomicrons to low density lipoprotein receptor-related protein. Proc. Natl. Acad. Sci. USA 88: 8342-8346

Beisiegel, U. (1996) New aspects on the role of plasma lipases in lipo-protein catabolism and atherosclerosis. Atherosclerosis 124: 1-8

Bensadoun, A. (1991) Lipoprotein lipase. Annu. Rev. Nut.r 11: 217-237

Bierman, E. L. (1992) Atherogenesis in diabetes. Arterioscler. Thromb. 12: 647-656

Bradford, M. M. (1976) A rapid and sensitive method for the quantitation of microgram quantities of protein utilizing the principle of protein-dye binding. Anal. Biochem. 72: $248-254$

Braun, J. E. and Severson, D. L. (1992) Tissue-specific regulation of lipoprotein lipase. Cmaj 147: 1192

Brown, M. S. and Goldstein, J. L. (1983) Lipoprotein metabolism in the macrophage: 
implications for cholesterol deposition in atherosclerosis. Annu. Rev. Biochem. 52: 223261

Camps, L., Reina, M., Llobera, M., Vilaro, S. and Olivecrona, T. (1990) Lipoprotein lipase: cellular origin and functional distribution. Am. J. Physiol 258: C673-681

Eckel, R. H. (1989) Lipoprotein lipase. A multifunctional enzyme relevant to common metabolic diseases. N. Engl. J. Med. 320: 1060-1068

Felts, J. M., Itakura, H. and Crane, R. T. (1975) The mechanism of assimil-ation of constituents of chylomicrons, very low density lipoproteins and remnants - a new theory. Biochem. Biophys. Res. Commun. 66: 1467-1475

Henderson, A. D., Richmond, W. and Elkeles, R. S. (1993) Hepatic and lipoprotein lipases selectively assayed in postheparin plasma. Clin. Chem. 39: 218-223

Hide, W. A., Chan, L. and Li, W. H. (1992) Structure and evolution of the lipase superfamily. J. Lipid Res. 33: 167-178

Hurt, E. and Camejo, G. (1987) Effect of arterial proteoglycans on the interaction of LDL with human monocyte-derived macrophages. Athero-sclerosis 67: 115-126

Kelley, J. L. and Kruski, A. W. (1986) Density gradient ultracentrifugation of serum lipoproteins in a swinging bucket rotor. Methods Enzymol. 128: 170-181

Klimov, A. N., Denisenko, A. D., Popov, A. V., Nagornev, V. A., Pleskov, V. M., Vinogradov, A. G., Denisenko, T. V., Magracheva, E., Kheifes, G. M. and Kuznetzov, A. S. (1985) Lipoprotein-antibody immune complexes. Their catabolism and role in foam cell formation. Atherosclerosis 58: 1-15

Laemmli, U. K. (1970) Cleavage of structural proteins during the assembly of the head of bacteriophage T4. Nature 227: 680-685

Masuno, H., Blanchette-Mackie, E. J., Schultz, C. J., Spaeth, A. E., Scow, R. O. and Okuda, H. (1992) Retention of glucose by N-linked oligosaccharide chains impedes expression of lipoprotein lipase activity: effect of castano-spermine. J. Lipid Res. 33: $1343-1349$

Merkel, M., Kako, Y., Radner, H., Cho, I. S., Ramasamy, R., Brunzell, J. D., Goldberg, I. J. and Breslow, J. L. (1998) Catalytically inactive lipoprotein lipase expression in muscle of transgenic mice increases very low density lipoprotein uptake: direct evidence that lipoprotein lipase bridging occurs in vivo. Proc. Natl. Acad. Sci. USA 95: 13841-13846

Mulder, M., Lombardi, P., Jansen, H., van Berkel, T. J., Frants, R. R. and Havekes, L. M. (1993) Low density lipoprotein receptor internalizes low density and very low density lipoproteins that are bound to heparan sulfate proteoglycans via lipoprotein lipase. J. Biol. Chem. 268: 9369-9375

Nilsson-Ehle, P. and Schotz, M. C. (1976) A stable, radioactive substrate emulsion for assay of lipoprotein lipase. J. Lipid Res. 17: 536-541

O'Brien, K. D. and Chait, A. (1994) The biology of the artery wall in atherogenesis. Med. Clin. North Am. 78: 41-67

Olivecrona, T. and Bengtsson-Olivecrona, G. (1987) Lipoprotein lipase from milk: The model enzyme in lipoprotein lipase research. In Lipoprotein lipase (Borensztajn, J., ed.), pp. 15-58, Evener Publishers, Chicago

Park, J. W., Oh, M. S., Yang, J. Y., Park, B. H., Rho, H. W., Lim, S. N., Jhee, E. C. and Kim,
H. R. (1995) Glycosylation, dimerization, and heparin affinity of lipoprotein lipase in 3T3L1 adipocytes. Biochim. Biophys. Acta 1254: 45-50

Park, J. W., Yang, J. Y., Rhee, S. R., Cho, C. G., Park, B. H., Rho, H. W., Kim, J. S. and Kim, H. R. (1996) Glycosylation of lipoprotein lipase in human subcutaneous lipomas. Horm. Metab. Res. 28: 7-10

Pitas, R. E. and Mahley, R. W. (1992) Analysis of tissue lipoproteins. In Lipoprotein analysis: a practical approach (Converse, C. A. and Skimmer, E. R. eds.), pp. 215-242, Oxford University Press, New York

Rutledge, J. C. and Goldberg, I. J. (1994) Lipoprotein lipase (LpL) affects low density lipoprotein (LDL) flux through vascular tissue: evidence that $L \mathrm{pL}$ increases $L D L$ accumulation in vascular tissue. J. Lipid Res. 35: 1152-1160

Salisbury, B. G., Falcone, D. J. and Minick, C. R. (1985) Insoluble low-density lipoprotein-proteoglycan complexes enhance cholesteryl ester accumulation in macrophages. Am. J. Pathol. 120: 6-11

Saxena, U., Klein, M. G. and Goldberg, I. J. (1991) Identification and characterization of the endothelial cell surface lipoprotein lipase receptor. J. Biol. Chem. 266: 17516-17521

Saxena, U., Klein, M. G., Vanni, T. M. and Goldberg, I. J. (1992) Lipoprotein lipase increases low density lipoprotein retention by subendothelial cell matrix. J. Clin. Invest. 89: $373-380$

Siedel, J., Hagele, E. O., Ziegenhorn, J. and Wahlefeld, A. W. (1983) Reagent for the enzymatic determination of serum total cholesterol with improved lipolytic efficiency. Clin. Chem. 29: 1075-1080

Steinberg, D., Parthasarathy, S., Carew, T. E., Khoo, J. C. and Witztum, J. L. (1989) Beyond cholesterol. Modifications of low-density lipoprotein that increase its atherogenicity. N. Engl. J. Med. 320: 915-924

Vijayagopal, P., Srinivasan, S. R., Xu, J. H., Dalferes, E. R., Jr., Radha-krishnamurthy, B. and Berenson, G. S. (1993) Lipoprotein-proteoglycan complexes induce continued cholesteryl ester accumulation in foam cells from rabbit atherosclerotic lesions. J. Clin. Invest. 91: 1011-1018

Vilella, E., Joven, J., Fernandez, M., Vilaro, S., Brunzell, J. D., Olivecrona, T. and Bengtsson-Olivecrona, G. (1993) Lipoprotein lipase in human plasma is mainly inactive and associated with cholesterol-rich lipoproteins. J. Lipid Res. 34: 1555-1564

Wahlfeld, A. W. (1974) Triglycerides: determination after enzymatic hydro-lysis. In Methods of enzymatic analysis (Bergmeyer, H. V., ed.), pp. 1831-1835 Academic Press, New York

Witztum, J. L. (1993) Role of oxidised low density lipoprotein in athero-genesis. Br. Heart J. 69: S12-18 